\title{
The Role of Sharing Peer Group Intervention on Nutritional Anemia Prevention to Children at Bayang Public Elementary School in Makassar City
}

\author{
Sumardi Sudarman ${ }^{1}$, Anto J. Hadi ${ }^{2}$, Jusman Usman ${ }^{3}$ \\ ${ }^{1}$ Lecturer of Public Health, Fakultas Kesehatan Masyarakat, Universitas Pancasakti, Makassar, Indonesia, \\ ${ }^{2}$ Lecturer of Public Health, Fakultas Kesehatan, Universitas Aufa Royhan, Padangsidimpuan, Indonesia, ${ }^{3}$ Lecturer \\ of Public Health, Fakultas Kesehatan Masyarakat, Universitas Indonesia Timur, Makassar, Indonesia
}

\begin{abstract}
The prevalence of nutritional anemia is one of elementary shool-aged children's nutritional problems and brings an impact on students' learning achievements. This study aimed to analyze the role of sharing peer group intervention on nutritional anemia prevention to elementary school-aged children. The research design used was quasi-experiment with control group design. Population and samples of students from IV and V classes were 54 and the students were chosen through purposive sampling method. Data were analyzed with paired test. Results showed that there were increment scores in cognitive aspect after sharing peer group method was applied as research intervention $(\mathrm{M}=24.07 ; \mathrm{SD}=11.851)$. The value was greater than cognitive scores increment after counseling method applied as research intervention $(\mathrm{M}=14.81 ; \mathrm{SD}=8.931)$ with $\mathrm{p}$ value $=0.002$ less than significance value $(p<0,05)$. It shows that there is increase of average increment to respondent's cognitive scores. Average increment affective scores of respondents after sharing peer group $(\mathrm{M}=25.55 ; \mathrm{SD}=15.275)$ was conducted is greater than counseling method $(\mathrm{M}=15.92 ; \mathrm{SD}=14.212)$ with $\mathrm{p}$ value $=0.020$ less than significance value $(p<0.05)$. It means that there is increase of average increment to respondent's affective scores. Average increment psychomotor scores of respondents after sharing peer $\operatorname{group}(\mathrm{M}=22.22 ; \mathrm{SD}=11.208)$ was conducted is greater than counseling method $(\mathrm{M}=15.18 ; \mathrm{SD}=11.559)$ with $\mathrm{p}$ value $=0.027$ less than significance value $(\mathrm{p}<0.05)$. It means that there is increase of average increment to respondent's psychomotor scores. It is expected to shool practitioners to continue the counseling and sharing peer group to students in order to maintain healthy food consumption pattern with sustainable and proper way so that students can avoid nutritional anemia cases.
\end{abstract}

Keywords: Nutritional Behavior, Sharing Peer Group, Nutritional Anemia.

\section{Introduction}

Nutritional anemia is generally found in nutrition vulnerable groups in elementary school-aged children ${ }^{(1)}$.

\section{Corresponding Author:}

\section{Sumardi Sudarman}

Department of Public Health, Fakultas Kesehatan

Masyarakat, Universitas Pancasakti, Makassar, Indonesia

Jl. Andi Mangerangi No.73, Mamajang Dalam, Kec. Mamajang, Kota Makassar, Sulawesi Selatan, Indonesia, 90132

Personal Phone Number: +62 813-5566-0848

e-mail: sumardimardi567@gmail.com
The World Health Organization (WHO) reports that the number of cases of nutritional anemia in the age group of elementary school-aged children in the Asian continent is $58.4 \%$. This value is higher than the number of cases of anemia in the school age group in the African continent, which is $49.8 \%{ }^{(2)}$. Based on the results of the Basic Health Research or Riset Kesehatan Dasar (Riskesdas) in 2013, it showed that iron nutritional anemia in children aged 5-12 years was 29\% and in Makassar City in particular it was $37.6 \%{ }^{(3)}$. A study of students in grades $4-6$ of elementary schools in Taiwan regarding the selection of healthy and unhealthy snacks found that around $31.8 \%$ of students rarely bought unhealthy snacks. The number of children who were obtained in this research as many as $78 \%$ of students ${ }^{(4)}$. Students who suffer nutritional 
anemia can cause low concentration which has an impact on decreasing learning achievement. This condition is allowed to be left to children which will have an impact on productivity levels and suffer degenerative diseases in the future ${ }^{(5)}$. Eating and buying snacks that are low in mineral nutrients, especially iron, have a negative impact on children's health ${ }^{(6)}$.

Nutritional anemia has an impact on decreasing the quality of human resources, especially in elementary school-aged children. The case we found in the literature review is related to the unfulfilled iron intake that can cause problems in the growth process of both body cells including the growth and development of brain cells. There is a decrease in hemoglobin levels in the blood so that it can cause symptoms of weakness, fatigue, tired and sluggish, which in turn can cause a decrease in learning achievement for school children and a decrease in work productivity. In addition, the effect that can be caused for someone who is deficient in iron will reduce the immune system or the body's immune system which results in susceptibility to the infection ${ }^{(7)}$.

Healthy snacking behavior can be used to educate children in choosing snacks according to 4 healthy 5 perfect meal combination campaigned by Indonesia health practitioners (4 sehat 5 sempurna). On average, each student buys between 2 and 3 types of snacks each time they buy meal or snack ${ }^{(8)}$. Snacks for children are very easy to obtain at relatively cheap prices, low in nutritional intake and for school children and are very dangerous for health. The purpose of this study was to analyze the effect of peer group sharing intervention on the prevention of nutritional anemia in children of the Bayang Public Elementary School in Makassar City, South Sulawesi.

\section{Research Methodology}

Quasi experiment research approach is used in this study. We conducted pretest and post-test to elaborate before and after intervention with control group design. The treatment group was given nutritional and health education as research intervention for three months through peer group sharing by giving nutrition posters and leaflets to elementary school children with nutritional anemia. In comparison, the control was not given intervention but we elaborated the research by providing only in the form of health counseling. The research stages included: preparation and processing of research permits; distribution of correspondence; initial data collection (hemoglobin measurement and health parameter screening); implementation of interventions; and monitoring and evaluation. This research was conducted at the Bayang Public Elementary School in Makassar City which had the same characteristics and had never been screened for nutritional anemia before. The population and samples were students suffered from nutritional anemia at Bayang Public Elementary School in Makassar City. The samples were chosen through a purposive sampling method. Samples were selected among the population according to the certain limitation set by the researcher based on the samples criteria. The research instrument was elementary school children who were selected as the research samples. The students as samples then would be checked for screening and hemoglobin $(\mathrm{Hb})$ levels by experts (health practitioners). Then we proceeded with questions and answers about diet and food consumption using the previously prepared interview guidelines (food frequency questionnaire). $\mathrm{Hb}$ level examination used the "Cyanmethemoglobin" method as recommended by the World Health Organization and the International Committee for Standardization in Hematology as well as a 24-hour food recall and analyzed using the Indonesian version of the 2007 Nutrisurvey software. Intervention media are nutrition posters and leaflets using peer group sharing.

\section{Results}

We collect data of respondents from certain characteristics which were class, intervention group, sharing peer group, and penyuluhan to the respondents themselves. The frequency of characteristics-based respondents can be seen in Table 1 to the total amount and percentage.

Table 1. Distribution of Characteristics-based Respondents

\begin{tabular}{|l|c|c|}
\hline Respondent's Characteristics & $\mathbf{n}$ & $\mathbf{\%}$ \\
\hline Class & & \\
IV & 26 & 48.2 \\
V & 28 & 51.8 \\
\hline Total & 54 & 100.0 \\
\hline Intervention Group & & \\
Sharing Peer Group & 27 & 50.0 \\
Counseling & 27 & 50.0 \\
\hline Total & $\mathbf{5 4}$ & $\mathbf{1 0 0 . 0}$ \\
\hline
\end{tabular}


Table 1 shows that the distribution of respondents based on class level. Of the 54 respondents, the most respondents were identified from class $\mathrm{V}$. There were 28 students $(51.8 \%)$ from total samples. The remaining 26 students $(48.2 \%)$ as respondents were identified from class IV. In addition, based on the intervention group, from 54 respondents there were 27 students (50\%) in each of the peer group sharing intervention and counseling intervention groups.

Table 2. Distribution of Students' Cognitive, Affective, and Psychomotor Scores Based on Sharing Peer Group Intervention

\begin{tabular}{|c|c|c|c|c|c|c|}
\hline \multirow{2}{*}{$\begin{array}{c}\text { Descriptive } \\
\text { Statistics }\end{array}$} & \multicolumn{2}{|c|}{ Cognitive Score } & \multicolumn{2}{c|}{ Affective Score } & \multicolumn{2}{c|}{ Psychomotor Score } \\
\cline { 2 - 7 } & Pretest & Post-test & Pretest & Post-test & Pretest & Post-test \\
\hline $\mathrm{n}$ & 27 & 27 & 27 & 27 & 27 & 27 \\
\hline Mean & 40.00 & 64.07 & 39.63 & 65.19 & 40.37 & 62.59 \\
SD & 12.710 & 7.473 & 11.260 & 8.490 & 8.540 & 6.559 \\
\hline p-Value & \multicolumn{3}{|c|}{0.000} & \multicolumn{2}{c|}{0.000} & \multicolumn{2}{c}{0.000} \\
\hline
\end{tabular}

Table 2 shows that students' cognitive aspect score about anemia increased after the implementation of health interventions with the peer group sharing method. The average post-test under cognitive score $(\mathrm{M}=64.07 ; \mathrm{SD}=7.473)$ was greater than the average pretest cognitive score $(\mathrm{M}=40.00 ; \mathrm{SD}=12.710)$ with the obtained $\mathrm{p}$ value $=0.000$. smaller than the significant value $(p<0.05)$. The average post-test affective score $(\mathrm{M}=65.19 ; \mathrm{SD}=8,490)$ is greater than the average pretest affective score $(\mathrm{M}=39.63 ; \mathrm{SD}=11.260)$ with the obtained $\mathrm{p}$ value $=0.000$, smaller than the value of significant value $(\mathrm{p}<0.05)$. The average post-test psychomotor score $(\mathrm{M}=62.59 ; \mathrm{SD}=6.559)$ greater than the average pretest psychomotor score $(\mathrm{M}=40.37 ; \mathrm{SD}=8.540)$ with the obtained $\mathrm{p}$ value $=0.000$, smaller than the significant value $(p<0.05)$. It means that there were significant differences in the average score of cognitive, affective, and psychomotor.

Table 3. Distribution of Students' Cognitive, Affective, and Psychomotor Scores Based on Counseling Intervention

\begin{tabular}{|c|c|c|c|c|c|c|}
\hline \multirow{2}{*}{$\begin{array}{c}\text { Descriptive } \\
\text { Statistics }\end{array}$} & \multicolumn{2}{|c|}{ Cognitive Score } & \multicolumn{2}{|c|}{ Affective Score } & \multicolumn{2}{|c|}{ Psychomotor Score } \\
\hline & Pretest & Post-test & Pretest & Post-test & Pretest & Post-test \\
\hline $\mathrm{n}$ & 27 & 27 & 27 & 27 & 27 & 27 \\
\hline Mean & 43.70 & 58.52 & 44.44 & 60.37 & 42.96 & 58.15 \\
\hline $\mathrm{SD}$ & 8.389 & 7.698 & 12.195 & 7.061 & 10.309 & 7.863 \\
\hline p-Value & \multicolumn{2}{|c|}{0.000} & \multicolumn{2}{|c|}{0.000} & \multicolumn{2}{|c|}{0.000} \\
\hline
\end{tabular}

Table 3 shows that students' cognitive aspect score about anemia increased after the implementation of health interventions with the counseling method. The average post-test under cognitive score $(\mathrm{M}=58.52 ; \mathrm{SD}=7.698)$ was greater than the average pretest cognitive score $(\mathrm{M}=43.70 ; \mathrm{SD}=8.389)$ with the obtained $\mathrm{p}$ value $=0.000$. smaller than the significant value $(\mathrm{p}<0.05)$. The average post-test affective score $(\mathrm{M}=60.37 ; \mathrm{SD}=7.061)$ is greater than the average pretest affective score $(M=44.44$;
$\mathrm{SD}=12.159)$ with the obtained $\mathrm{p}$ value $=0.000$, smaller than the value of significant value $(\mathrm{p}<0.05)$. The average post-test psychomotor score $(\mathrm{M}=58.15 ; \mathrm{SD}=7.863)$ greater than the average pretest psychomotor score $(\mathrm{M}=42.96 ; \mathrm{SD}=10.309)$ with the obtained $\mathrm{p}$ value $=0.000$, smaller than the significant value $(p<0.05)$. It means that there were significant differences in the average score of cognitive, affective, and psychomotor. 
Table 4. Achievement Comparison on Students' Cognitive, Affective, and Psychomotor Scores Between Sharing Peer Group and Counseling Intervention

\begin{tabular}{|c|c|c|c|c|c|c|}
\hline \multirow{2}{*}{$\begin{array}{c}\text { Descriptive } \\
\text { Statistics }\end{array}$} & \multicolumn{2}{|c|}{ Cognitive Score Increment } & \multicolumn{2}{|c|}{ Affective Score Increment } & \multicolumn{2}{|c|}{ Psychomotor Score Increment } \\
\hline & $\begin{array}{c}\text { Sharing Peer } \\
\text { Group }\end{array}$ & Counseling & $\begin{array}{c}\text { Sharing Peer } \\
\text { Group }\end{array}$ & Counseling & $\begin{array}{c}\text { Sharing Peer } \\
\text { Group }\end{array}$ & Counseling \\
\hline $\mathrm{n}$ & 27 & 27 & 27 & 27 & 27 & 27 \\
\hline Mean & 24.07 & 14.81 & 25.55 & 15.92 & 22.22 & 15.18 \\
\hline $\mathrm{SD}$ & 11.851 & 8.931 & 15.275 & 14.212 & 11.208 & 11.559 \\
\hline p-Value & \multicolumn{2}{|c|}{0.002} & \multicolumn{2}{|c|}{0.020} & \multicolumn{2}{|c|}{0.027} \\
\hline
\end{tabular}

Table 4 shows the results of achievement comparison of students' cognitive, affective, and psychomotor scores on each aspect. There were difference results between sharing peer group and counseling as intervention in this study. The results show that there were increment scores in cognitive aspect after sharing peer group method was applied as research intervention $(M=24.07$; $\mathrm{SD}=11.851$ ). The value was greater than cognitive scores increment after counseling method applied as research intervention $(\mathrm{M}=14.81 ; \mathrm{SD}=8.931)$ with $\mathrm{p}$ value $=0.002$ less than significance value $(\mathrm{p}<0,05)$. It shows that there is increase of average increment to respondent's cognitive scores. Average increment affective scores of respondents after sharing peer group $(M=25.55$; $\mathrm{SD}=15.275)$ was conducted is greater than counseling method $(\mathrm{M}=15.92 ; \mathrm{SD}=14.212)$ with $\mathrm{p}$ value $=0.020$ less than significance value $(\mathrm{p}<0.05)$. It means that there is increase of average increment to respondent's affective scores. Average increment psychomotor scores of respondents after sharing peer group $(M=22.22$; $\mathrm{SD}=11.208)$ was conducted is greater than counseling method $(\mathrm{M}=15.18 ; \mathrm{SD}=11.559)$ with $\mathrm{p}$ value $=0.027$ less than significance value $(\mathrm{p}<0.05)$. These results show that there were significant differences of using sharing peer group and counseling as nutritional anemia prevention; which became research intervention.

\section{Discussion}

Nutritional anemia suffered by elementary schoolaged children is influenced by diet, nutritional intake, and infectious diseases. Nutritional anemia are mostly experienced by students ${ }^{(9)}$. In addition, the eating behavior of elementary school children on average is not more than three times a day. In our study, the eating behavior that is categorized as "eating" is not only in the context of consuming staple foods but snacking are also categorized as eating ${ }^{(10)}$. The cases of nutritional problems were very much influenced by the knowledge (cognitive), attitudes (affective), and behavior (psychomotor) about healthy lifestyle and nutrition intake understood and applied by children daily. It will cause an inner response in the form of action through prevention of nutritional anemia. Students are positive because they get information about nutritional anemia from the teacher who currently teaches the class. Of students being observed as the respondents, there are also students who do not know the impact and dangers of nutritional anemia as they have not been taught properly about it. According to Duque (2014), anemia can be caused by a lack of iron nutrients intake in food, either due to inappropriate food consumption patterns, inadequate quality and quantity of food, or due to an increase in iron needs ${ }^{(11)}$.

The main problem with iron nutrients utilization by the body is the low absorption in the intestines. The absorption of iron nutrients is influenced by two factors, namely the absorption of heme and nonheme iron. These processes indicate the presence of two different types of iron in food. Sources of heme in human food are meat, fish and poultry, while nonheme sources of food to consume are cereals, nuts, vegetables and fruit. The type of tea that is often consumed by respondents is tea in glass (instant tea with additive flavour). This kind of snack or specifically drink is currently very popular with children and the community. Instant tea is very affordable and fash-ordered because it is easily sold at a relatively cheap price with cold condition. Other types of foods that inhibit iron absorption are very rarely consumed because the respondent's favorite type of food is milk ${ }^{(12)}$. Less than a third of children have a good knowledge of substitute foods, which is especially important for people with limited purchasing power. Replacing certain types of food with other foods that are inexpensive but still have an equivalent 
nutritional content will be able to overcome some of the completeness of nutrient intake $e^{(13)}$.

The results obtained showed the comparison of the average increase in the score of knowledge (cognitive), attitudes (affective), and behavior (psychomotor) of students as respondents about healthy lifestyle and nutritional anemia after the implementation of health interventions with peer group sharing and counseling method. The average increase in students' knowledge (cognitive scores) after the implementation of health interventions with sharing peer group method was greater than the average increase of counseling group method. Not only cognitive aspect, the average increase in affective and psychomotor at pretest (before intervention) and post-test (after intervention) scores due to sharing peer group method is better than only counseling method. Based on these findings, it can be concluded that the health intervention using the peer group sharing method is better in increasing the score of cognitive, affective, and psychomotor aspects of elementary school-aged children as respondents of this study about nutritional anemia than the only counseling method. These results generally illustrate that children's knowledge, attitudes, and actions about food are still not stable and require more complete information. This needs to be balanced with the correct understanding, that nutritional anemia is indeed very dangerous cases for health and nutrition as well as productivity levels ${ }^{(14)}$. Nearly all the children stated that they should have breakfast before going to school; half said that they should eat every day. These statements can describe their daily practice and biologically reflect the increased nutritional requirements at this age. Some of the knowledge, attitudes and actions of school students are already good, but they still need to be improved properly.

The results of the study were supported by Astina's research (2016) at Public Elementary School Pasanggrahan 1, Purwakarta Regency. The results show that the attitudes of elementary school children mostly supported as much as $60 \%$ with good nutritional anemia prevention measures as many as 24 elementary school children $(45 \%){ }^{(15)}$. The attitude in choosing snacks for children with nutritional anemia is not only formed from the knowledge they have, but is also influenced by the culture and educational institutions where the children go to school ${ }^{(16)}$. The peer group sharing approach given to students with nutritional anemia material can change most aspects of knowledge and attitudes of students in a positive direction. However, this approach is not sufficient to change student actions, possibly because the consumption pattern of students is still very dependent on the actions of the teachers, while the intervention is not aimed at teachers but at students. However, we did not elaborate longitudinal research approach so that the short intervention time has not been able to change the nutritional behavior as expected. Overall, learning and counseling for elementary school children about nutritional anemia has great potential to change children's diet plan. Not much different from nutritional knowledge on cognitive aspect, most students agreed not to eat much or snacking food too often ${ }^{(17)}$. To determine the change in knowledge, attitudes, and actions of students after the intervention, bivariate analysis under statistics measurements was carried out. In general, in the second measurement, the mean score of children's knowledge, attitudes, and actions regarding nutritional anemia had increased after the peer group sharing method was applied.

\section{Conclusion}

There is an effect of peer group sharing method and counseling method on the nutritional behavior of nutritional anemia students. Health and educational practitioner parties in the scope of the school can work together in providing education to students on how to prevent and overcome cases of nutritional anemia in order to improve the quality of health and student learning achievement. The research address to perform further research on various state.

Ethical Clearance: Ethical approval has been obtained from Ethical Commission of Health Research, Faculty of Public Health.

Source of Funding: This research was supported by the Directorate of Research and Community Service, the Directorate General of Research and Development Strengthening Indonesia.

Conflict of Interest: The author(s) declare that they have no conflict of interest

\section{References}

1. Abdullah K, Thorpe KE, Maguire JL, Birken CS, Fehlings D, Hanley AJ, et al. Risk factors, practice variation and hematological outcomes of children identified with non-anemic iron deficiency following screening in primary care setting. Paediatr Child Health. 2015;20(6):302-6. 
2. Akodu OS, Disu EA, Njokanma OF, Kehinde OA. Iron deficiency anaemia among apparently healthy pre-school children in Lagos, Nigeria. Afr Health Sci. 2016;16(1):61-8.

3. KEMENKES RI, Indonesia KKR. Riset kesehatan dasar 2013. Badan Penelit dan Pengemb Kementeri Kesehat RI, Jakarta. 2013;

4. Su J, Cui N, Zhou G, Ai Y, Sun G, Zhao SR, et al. Hemoglobin status and externalizing behavioral problems in children. Int $\mathrm{J}$ Environ Res Public Health. 2016;13(8):758.

5. Cardoso MA, Augusto RA, Bortolini GA, Oliveira CSM, Tietzman DC, Sequeira LAS, et al. Effect of providing multiple micronutrients in powder through primary healthcare on anemia in young Brazilian children: a multicentre pragmatic controlled trial. PLoS One. 2016;11(3):e0151097.

6. Raiten DJ, Neufeld LM, De-Regil L-M, Pasricha S-R, Darnton-Hill I, Hurrell R, et al. Integration to implementation and the Micronutrient Forum: A coordinated approach for global nutrition. Case study application: Safety and effectiveness of iron interventions. Adv Nutr. 2016;7(1):135-48.

7. El Menchawy I, El Hamdouchi A, El Kari K, Saeid N, Zahrou FE, Benajiba N, et al. Efficacy of multiple micronutrients fortified milk consumption on iron nutritional status in Moroccan schoolchildren. J Nutr Metab. 2015;2015.

8. Amelia K. Hubungan Pengetahuan Makanan dan Kesehatan dengan Frekuensi Konsumsi Makanan Jajanan Pada Anak Sekolah Dasar Pembangunan Laboratorium Universitas Negeri Padang. E-Journal Home Econ Tour. 2013;2(1).

9. Bar-Zeev SJ, Kruske SG, Barclay LM, Bar-Zeev N, Kildea S V. Adherence to management guidelines for growth faltering and anaemia in remote dwelling Australian Aboriginal infants and barriers to health service delivery. BMC Health Serv Res. 2013;13(1):250.
10. Davey C, Aiken AM, Hayes RJ, Hargreaves JR. Re-analysis of health and educational impacts of a school-based deworming programme in western Kenya: a statistical replication of a cluster quasirandomized stepped-wedge trial. Int J Epidemiol. 2015;44(5):1581-92.

11. Duque X, Martinez H, Vilchis-Gil J, Mendoza E, Flores-Hernández S, Morán S, et al. Effect of supplementation with ferrous sulfate or iron bis-glycinate chelate on ferritin concentration in Mexican schoolchildren: a randomized controlled trial. Nutr J. 2014;13(1):71.

12. Neunert CE, Gibson RW, Lane PA, VermaBhatnagar P, Barry V, Zhou M, et al. Determining adherence to quality indicators in sickle cell anemia using multiple data sources. Am J Prev Med. 2016;51(1):S24-30.

13. Erismann S, Knoblauch AM, Diagbouga S, Odermatt P, Gerold J, Shrestha A, et al. Prevalence and risk factors of undernutrition among schoolchildren in the Plateau Central and CentreOuest regions of Burkina Faso. Infect Dis poverty. 2017;6(1): 17 .

14. Mesfin F, Berhane Y, Worku A. Anemia among primary school children in Eastern Ethiopia. PLoS One. 2015;10(4):e0123615.

15. Astina J. Pengaruh status gizi dan status anemia terhadap daya ingat sesaat siswa di SDN Pasanggrahan 1 kabupaten Purwakarta. J Gizi dan Pangan. 2012;7(2):103-10.

16. Abdulsalam M, Daniel A. Diagnosis, pengobatan dan pencegahan anemia defisiensi besi. Sari Pediatr. 2016;4(2):74-7.

17. Iannotti L, Dulience SJ-L, Joseph S, Cooley C, Tufte T, Cox K, et al. Fortified Snack Reduced Anemia in Rural School-Aged Children of Haiti: A Cluster-Randomized, Controlled Trial. PLoS One. 2016;11(12):e0168121. 